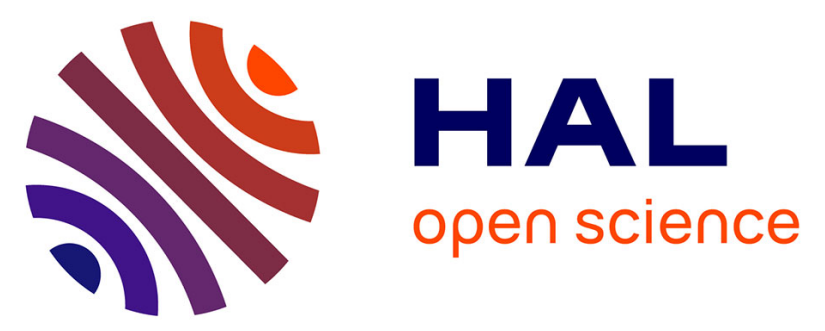

\title{
BENOIST PIERRE, La monarchie ecclésiale. Le clergé de cour en France à l'époque moderne, Seyssel, Champ Vallon, 2013, 460 p., ISBN 978-2-87673-883-6
}

Thomas Nicklas

\section{- To cite this version:}

Thomas Nicklas. BENOIST PIERRE, La monarchie ecclésiale. Le clergé de cour en France à l'époque moderne , Seyssel, Champ Vallon, 2013, 460 p., ISBN 978-2-87673-883-6. Revue d'Histoire Moderne et Contemporaine, 2019, pp.175-176. 10.3917/rhmc.662.0175 . hal-02554783

\section{HAL Id: hal-02554783 \\ https://hal.univ-reims.fr/hal-02554783}

Submitted on 1 Nov 2021

HAL is a multi-disciplinary open access archive for the deposit and dissemination of scientific research documents, whether they are published or not. The documents may come from teaching and research institutions in France or abroad, or from public or private research centers.
L'archive ouverte pluridisciplinaire HAL, est destinée au dépôt et à la diffusion de documents scientifiques de niveau recherche, publiés ou non, émanant des établissements d'enseignement et de recherche français ou étrangers, des laboratoires publics ou privés.

\section{(c)(1)}

Distributed under a Creative Commons Attribution| 4.0 International License 
- BENOIST PIERRE, La monarchie ecclésiale. Le clergé de cour en France à l'époque moderne, Seyssel, Champ Vallon, 2013, 460 p., ISBN 978-2-87673-883-6

\section{- Thomas Nicklas, université de Reims Champagne-Ardenne}

Dès sa parution en 2013, ce livre est appelé à jouer un rôle important pour l'histoire religieuse et politique française de l'époque moderne. Benoist Pierre y a soumis le clergé de cour, principal pilier de la monarchie sacrale et administrative, à une analyse diachronique mettant l'accent sur l'évolution qu'il connut aux XVI et $\mathrm{XVII}^{\mathrm{e}}$ siècles. Composé de la maison ecclésiastique du roi (la Chapelle), avec à sa tête le grand aumônier de France suivi des confesseurs et des prédicateurs de la cour, ainsi que des «prélats d'État»(C. Michon) appartenant au Conseil du roi, ce clergé aulique fut un groupe bien identifié, distingué du reste de la cour. Son identité socioculturelle propre le situa entre les ecclésiastiques «hors cour » et les courtisans. Ces clercs auliques furent dispensés de résidence et de certaines restrictions de l'état ecclésiastique: on les autorisa par exemple à porter la barbe (interdite par le droit canon), et ils s'investirent dans le service politique et religieux du prince, en faveur de la monarchie centralisée, dans les domaines de la finance, de la justice et de la diplomatie. Évitant les lourdeurs d'une étude prosopographique, le livre envisage l'action collective d'un groupe bien défini, entre l'âge d'or du clergé de cour (1480-1560), les temps de crises sur fond de conflits fondamentaux (1560-1610) et la période des cardinaux-ministres (1615/1617-1661), apogée d'une monarchie ecclésiale que d'aucuns voulaient renouveler après la disparition du Roi Soleil, en se heurtant cependant aux oppositions réunies des forces jansénistes et gallicanes.

Élément important de la construction de l' «État moderne » en France et ailleurs, puisque délié des liens féodaux et vassaliques, le clergé de cour dépendait uniquement du roi. Louis d'Amboise sous Charles VIII et Georges d'Amboise sous Louis XII inaugurèrent en quelque sorte ce nouveau modèle du prélat de cour, se partageant entre le Conseil et la Chapelle royale. Sous le règne de François ${ }^{\text {er }}$, une génération de clercs mus par l'évangélisme humaniste d'Érasme entendit faire de la cour un levier pour réformer l'État et l'Église. Or le grand cataclysme des guerres de Religion fragilisa la position du clergé de cour, notamment après le coup de force d'Henri III qui fit assassiner «monstrueusement» le cardinal de 
Guise au château de Blois en décembre 1588, portant ainsi un coup fatal à la monarchie ecclésiale du temps des Valois. L'épisode éphémère du cardinal-roi Charles X (Charles de Bourbon, cardinal de Vendôme), à la suite de l'assassinat d'Henri III, montra bien à quel degré fut troublé l'équilibre des relations entre la monarchie et son clergé de service.

Après 1590, le clergé de cour s'est recomposé autour d'un projet à la fois politique et religieux : convertir le nouveau roi Henri IV et sa cour au catholicisme. L'attitude conciliante du Bourbon permit le ralliement du clergé au monarque et la refondation de l'Église de cour. Cependant, la restauration de la monarchie ecclésiale fut poussée plus loin. Lors des états généraux de 1615, l'évêque de Luçon, Richelieu, demanda le rétablissement du clergé dans ses premiers honneurs, faisant sien le concept d'une reconquête des conseils par les prélats, éloignés du centre de décision sous le règne d'Henri IV. Installé au cœur du pouvoir royal, à partir de 1624, le cardinal-ministre bénéficia d'un choix stratégique de Louis XIII qui s'était résolu à accorder la priorité à un membre éminent du clergé afin de centraliser la relation à l'Église. En effet, Richelieu entendait incarner la figure idéale du clergé aulique. Le cardinal se référait volontiers à l'un des grands personnages historiques de l'Église de cour, Georges d'Amboise, qu'il appréciait tout particulièrement et dont il fit rédiger une apologie par son historiographe Jean Sirmond. Ce livre, sorti en 1631, chanta les louanges de la monarchie ecclésiale rétablie et du ministre Richelieu; dont les grandes qualités illustreraient à merveille cette tradition française mettant les plus éminents représentants du clergé au service de l'État.

La période de splendeur, sous les ministères de Richelieu et de Mazarin, fut aussi celle qui souleva d'une manière fondamentale la question de l'agencement du politique et du religieux. Face à Richelieu, adversaire résolu des dévots et allié des puissances protestantes contre les Habsbourg, et face à Mazarin qui, d'après son biographe Antoine Aubéry (1688), ne fut bon chrétien qu'au moment de sa mort, une bonne partie du clergé remit en cause le sacerdoce d'État ostentatoire des deux ministres. Après la mort de Mazarin, le moment était venu de procéder à un recentrage de l'action politique du clergé aulique sur des objectifs religieux et spirituels. Le roi aurait-il seul profité de la monarchie ecclésiale au détriment de l'Église ? L'exemple du cardinal de Coislin, évêque d'Orléans depuis 1665 et grand aumônier de France, est assez révélateur dans ce contexte. Ce grand prélat réformateur voulait agir dans le cadre de son diocèse, mais pas dans celui de la cour, l'espace aulique restant très éloigné de ses préoccupations 
pastorales. Après la mort de Louis XIV, un vaste travail de légitimation est entrepris pour remettre en valeur le rôle de l'Église de cour dans les siècles passés et pour éclairer l'action des grands cardinaux-ministres. L'abbé Louis Legendre publia sa Vie du cardinal d'Amboise (1724) et le père jésuite Charles Fleury édita une Histoire du cardinal de Tournon, ministre de France (1728), en emboîtant le pas à l'abbé Louis Archon, chapelain du roi et auteur d'une Histoire de la Chapelle des rois de France (1704-1711). Ces publications de tendance apologétique contribuèrent à ce que le ministériat d'un prélat demeurât une option politique tout au long des règnes de Louis XV et de Louis XVI. Le rôle des cardinaux Dubois, Fleury ou Loménie de Brienne est instructif à cet égard. Or le dernier avait déjà dû se retirer du pouvoir en France, lorsqu'il fut élevé au cardinalat en décembre 1788. Il est très souhaitable que le clergé de cour du XVIII ${ }^{e}$ siècle soit également soumis à l'excellente grille d'analyse appliquée dans l'ouvrage de B. Pierre.

Une telle étude permettrait de connaître encore mieux cette cléricature de service qui a joué un rôle si important dans l'histoire des rapports de pouvoir et des modes de gouvernement de la France à l'époque moderne. Qui plus est, l'historiographe de Richelieu, J. Sirmond, a déjà insisté sur le fait que la plupart des rois d'Europe s'étaient constamment entourés, depuis la fin de l'époque médiévale, d'éminents prélats pour s'occuper de leurs affaires. Par conséquent, l'étude comparative du clergé de cour en Europe, depuis la fin du Moyen Âge, serait un sujet de recherche digne de l'attention des historiens. 